Journal of Bangladesh Chemical Society, Vol. 25(2), 166-179, 2012

\title{
INFLUENCE OF CAFFEINE ON THE REDOX CHARACTERISTICS OF IRON IN AQUEOUS SOLUTION
}

\author{
MD. ABDUL JABBAR*, MD. HUMAYUN KABIR AND REAZ AHMED CHOWDHURY
}

Department of Chemistry, University of Dhaka, Dhaka-1000, Bangladesh

\section{Abstract}

Electrochemical investigation of the influence of caffeine on the redox behaviour of iron (Fe) was studied by using cyclic voltammetry (CV) and chronocoulometry (CC) in aqueous solution. It was found that caffeine retards the heterogeneous charge transfer of $\mathrm{Fe}$ due to the formation of Fe-caffeine complex. Qualitative information for the formation of Fe-caffeine complex was obtained from CV and CC data. Job's plot suggested that a 1:1 complex of Fe-caffeine was formed in aqueous media. The active center of caffeine for the formation of Fe-caffeine complex was found between $\mathrm{O}(33)$ and $\mathrm{O}(34)$ position, revealed from MOPAC (Semi-empirical computation, molecular orbital package-PM3) computation.

\section{Introduction}

Caffeine is a bitter, white crystalline xanthine alkaloid and a psychoactive stimulant. It was isolated from coffee in 1820 by a German chemist, Friedlieb Ferdinand Runge. Caffeine, chemically known as 1,3,7-trimethyl-3,7-dihydro-purine-2,6-dione (Scheme 1), is consumed through processed cocoa, coffee, tea or kola nut based foods and beverages, stimulants, drugs and cosmetics. ${ }^{1}$

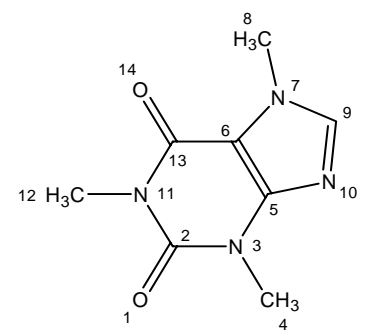

Scheme 1. Structure of caffeine (1,3,7-trimethyl-3,7-dihydro-purine-2,6-dione)

It is established that caffeine interferes with the body's absorption of iron ( $\mathrm{Fe})$, which is necessary for red blood cell production. ${ }^{2}$ Drinking caffeine at the same time as an Fe source can reduce absorption by up to $80 \%$, according to the Nutrition Desk Reference. ${ }^{3}$ Any beverage containing caffeine should be separated from Fe-containing foods or supplements by at least one hour prior to take caffeine. Coffee and tea are obvious sources of caffeine. Even decaffeinated versions contain a little residual caffeine. A cup

*Author for Correspondance; e-mail: jabbar@univdhaka.edu 
of coffee or green tea a day is not likely to have a negative effect on overall health. However, in excess, caffeine can cause nutrient deficiencies that can affect both health and quality of life. ${ }^{3-4}$ The metabolism and toxicity of caffeine is dose dependent resulting in non-linear accumulation of the methylxanthines, hence it possesses a greater risk of cardiovascular diseases ${ }^{5}$, such as, heart failure, high blood pressure and neuronal disorder $^{6}$, such as schizophrenia. Metabolic derangement and subsequent toxicity of caffeine leads to weight loss, poor growth, low protein efficiency ratio and poor nitrogen retention, leading to death. ${ }^{3,7}$ Thus, the toxicity of caffeine is viewed as a disposition demonstrating that caffeine is rapidly absorbed but slowly excreted. Caffeine also acts to increase alertness, anxiety and hallucination due to its blocking of adenosine receptors, ${ }^{8-10}$ which normally inhibits glutamate release. ${ }^{11}$

The beneficial effect of caffeine on Fe absorption has been attributed to the reductive and chelating power of caffeine, but the actual mechanism is still poorly understood. Recent study shows that caffeine enhances the reduction of iron at an upper $\mathrm{pH}$ limit. ${ }^{12}$ But at a physiological $\mathrm{pH}$, the effect of caffeine on iron is still poorly understood. This situation prompted us to study the redox characteristics, charge transfer rate and mechanism of caffeine in the presence and absence of Fe. This will help to find out the actual mechanism for its effect on $\mathrm{Fe}$. We have also in our mind that the electrochemical techniques, which employed in the present study, would have the similarities with enzymatic redox reactions ${ }^{13}$ and it is likely that the study of the electrochemical process of naturally occurring purines could help, at least in part, in understanding the complex mechanism of enzymatic and perhaps in vivo reactions.

\section{Experimental}

Cyclic voltammetry (CV), chronocoulometry (CC), differential pulse voltammetry (DPV) and UV-Visible spectroscopy were employed in the present study. CV and DPV were employed to find out the redox characteristics of caffeine, iron $(\mathrm{Fe})$ and $\mathrm{Fe}$ in the presence of caffeine. CC data will provide heterogeneous charge transfer kinetic and adsorption data of the above species. Job's plot was obtained from UV-Visible spectroscopic data provides the speciation of Fe-caffeine complex Details of the instrumentation and experimental set up are given below.

\section{Apparatus}

All the voltammetric experiments (CV and DPV) were carried out by using an Electrochemical Analyzer (Advanced Analytics, USA, Model HQ-2040) connected to a three-electrode micro cell consisting of a platinum working electrode, $\mathrm{Ag} / \mathrm{AgCl}$ reference electrode and a Pt-wire counter electrode. The cell is completely shielded from any perturbing noises by a Faraday cage (C-3 cell stand, Bioanalytical System Inc. (BASi) USA. The Faraday Cage is connected to a nitrogen gas cylinder to ensure diffusion controlled experiments. A continuous flow of $\mathrm{N}_{2}$ was confirmed prior to any experiment for inert atmosphere. The UV-Visible spectrophotometer, Model UV-1650A, Shimadzu, Japan, has an automatic digital display system for absorbance and a one centimeter 
quartz-cell was used to measure the absorbance. Theoretical calculation was done by using Chem-3D Pro, version 7.0, CS-MOPAC Std., (Semi-empirical Computation, Molecular Orbital Package), Cambridge Soft Corporation, 2002.

Chemicals

Caffeine was procured from BDH, England and was used without further purification. Hydrated Ferrous sulphate was purchased from Merck and was also used in the experiment without further purification. All the solutions were prepared from de-ionized water obtained from a milli-Q-water plant PURIC, Model-S. The experimental solutions were degassed with $99.99 \%$ commercially available nitrogen gas from BOL, Dhaka, Bangladesh and all the runs were taken under $\mathrm{N}_{2}$ atmosphere.

\section{Results and Discussion}

Cyclic voltammetry (CV) was adopted to find out the redox properties of iron (Fe), caffeine and caffeine in the presence of Fe. This will also give the qualitative information on the interaction between caffeine and Fe by comparing the voltammetric data. From the $\mathrm{CV}$ data we also calculate diffusion co-efficient (D) and heterogeneous charge transfer rate constant $\left(k_{\mathrm{f}}\right)$ for the above species. This will also allow us to compare the D and $k_{\mathrm{f}}$ values between iron $(\mathrm{Fe})$, caffeine and caffeine in the presence of $\mathrm{Fe}$ during the diffusion process. We also calculate the $\mathrm{D}$ and $k_{\mathrm{f}}$ values at the initial stage of diffusion adjacent to the bulk layer by using double potential step chronocoulometric (CC) data. CC data also enables to give the idea on adsorption of different species on the electrode surface. The idea about the interaction between caffeine and $\mathrm{Fe}$ was also evaluated by differential pulse voltammetric data. UV-visible spectroscopy enables to give the qualitative information of the interaction between caffeine and iron and specify the formation of the complex between these two species from the construction of Job's plot.

\section{Redox behavior of iron in aqueous solution}

Iron $(\mathrm{Fe})$ shows one step reversible redox reaction at different scan rates (Figure 1a) with a platinum disc electrode in aqueous $\mathrm{KCl}$ solution in the presence of small amount of $\mathrm{NaOH}$ solution to adjust the $\mathrm{pH}$ at 7.4. The corresponding current-voltage data is tabulated in Table 1. From the current-voltage data, it has been observed that the peak current ratio $\left(\mathrm{i}_{\mathrm{pa}} / \mathrm{i}_{\mathrm{pc}}\right)$ is unity and the ratio decreases from unity with increase in scan rate. The $\Delta \mathrm{E}_{\mathrm{p}}$ values arbitrarily constant with increase in scan rate. These are the diagnostic criteria for cyclic voltammetry with a reversible charge transfer. ${ }^{14}$ As the response virtually not broadens with scan rate $(v)$ increased, Fe shows a reversible charge-transfer according to literature. ${ }^{14}$ For reversible process, peak current $\left(i_{p}\right)$ represented according to the Randless-Sevcik equation as follows. ${ }^{14}$

$$
\mathrm{I}_{\mathrm{p}}=2.69 \times 10^{5} \mathrm{n}^{3 / 2} \mathrm{~A} \mathrm{D}^{1 / 2} \mathrm{C} v^{1 / 2}
$$

where, ' $\mathrm{n}$ ' is the number electrons involved in the electrochemical process, ' $A$ ' is the electrode are, ' $\mathrm{D}$ ' is the diffusion co-efficient, ' $\mathrm{C}$ ' is the bulk concentration and ' $v$ ' is the 
scan rate. Taking the calculated electrode area, $\mathrm{A}=0.025 \mathrm{~cm}^{2}, \mathrm{n}=1$ and $\mathrm{c}=1.2 \times 10^{-3}$ $\mathrm{M}$, the diffusion co-efficient (D) was calculated from the slope of the plot of $\mathrm{I}_{\mathrm{pa}} v s . v^{1 / 2}$ (Figure $1 \mathrm{~b}$, for both anodic and cathodic peak currents) and the calculated value was found as $5.87 \times 10^{-6} \mathrm{~cm}^{2} / \mathrm{sec}$, which is very close to the literature value.
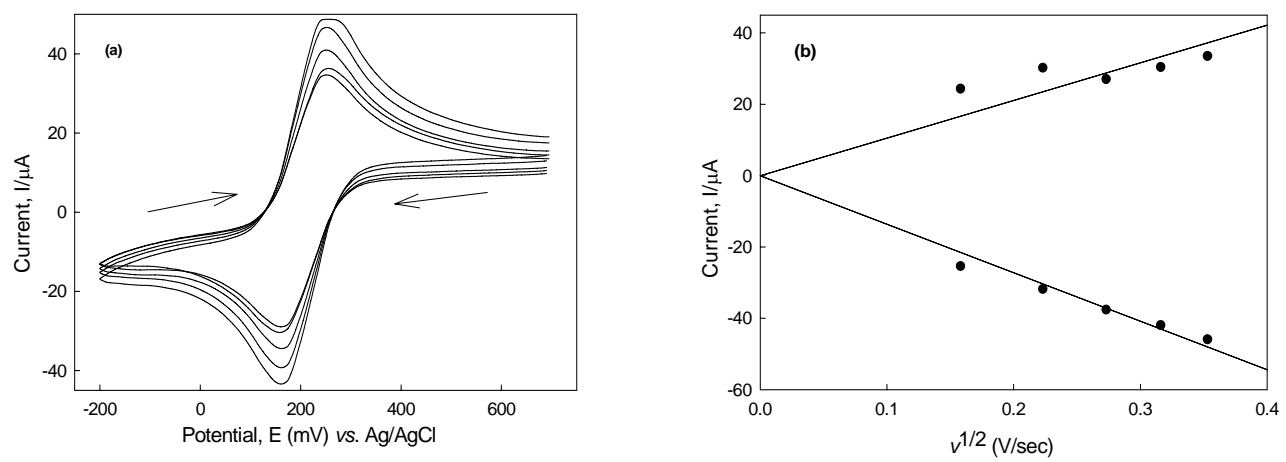

Fig. 1(a). $\mathrm{CV}$ of $1.2 \times 10^{-3} \mathrm{M} \mathrm{Fe}(\mathrm{II})$ in a mixture of aqueous $\mathrm{KCl}$ and $\mathrm{NaOH}$ solution (pH 7.4) with a Pt-disc electrode at different scan rates and (b). Variation of anodic and cathodic peak currents with the square root of scan rates for the same solution.

Table 1. Current-potential data and calculated parameters from the CV of Fe (II) at different scan rates

\begin{tabular}{cccccccc}
\hline $\begin{array}{c}v \\
\mathrm{~V} / \mathrm{sec}\end{array}$ & $\sqrt{v}_{(\mathrm{V} / \mathrm{sec})^{1 / 2}}$ & $\mathrm{E}_{\mathrm{pa}} / \mathrm{mV}$ & $\mathrm{E}_{\mathrm{pc}} / \mathrm{mV}$ & $\mathrm{I}_{\mathrm{pa}} / \mu \mathrm{A}$ & $\mathrm{I}_{\mathrm{pc}} / \mu \mathrm{A}$ & $\Delta \mathrm{E}_{\mathrm{p}} / \mathrm{mV}$ & $\mathrm{I}_{\mathrm{pa}} / \mathrm{I}_{\mathrm{pc}}$ \\
\hline 0.025 & 0.158 & 250 & 166 & 24.35 & 25.36 & 84 & 0.96 \\
0.050 & 0.223 & 257 & 164 & 30.24 & 31.77 & 90 & 0.95 \\
0.075 & 0.273 & 254 & 166 & 27.06 & 37.57 & 88 & 0.72 \\
0.100 & 0.316 & 254 & 163 & 30.42 & 41.93 & 91 & 0.73 \\
0.125 & 0.353 & 254 & 163 & 33.53 & 45.87 & 91 & 0.73 \\
\hline
\end{tabular}

$v=$ scan rate $; \mathrm{E}_{\mathrm{pa}}=$ anodic peak potential; $\mathrm{E}_{\mathrm{pc}}=$ cathodic peak potential; $\mathrm{I}_{\mathrm{pa}}=$ anodic peak current;

$\mathrm{I}_{\mathrm{pc}}=$ cathodic peak current; $\Delta \mathrm{E}_{\mathrm{p}}=\left(\mathrm{E}_{\mathrm{pa}}-\mathrm{E}_{\mathrm{pc}}\right)=$ peak separation

The heterogeneous charge transfer rate constant was calculated by using the following equation (2), which is applied typically for pure diffusion controlled process. ${ }^{14}$

$$
\mathrm{I}_{\mathrm{p}}=\mathrm{n} f \mathrm{~A} k_{\mathrm{f}} \mathrm{C}
$$

Where, $f=$ constant $=\mathrm{F} / \mathrm{RT}$; $\mathrm{F}$ is the Faraday constant and $\mathrm{T}$ is the absolute temperature; $k_{\mathrm{f}}$ is the heterogeneous charge transfer rate constant. By plotting peak current, Ip (either cathodic or anodic) vs. concentration of $\mathrm{Fe}$ (not shown in the Figure), $k_{\mathrm{f}}$ was obtained from the slope. The calculated $k_{\mathrm{f}}$-value was recorded as $16.06 \mathrm{~cm} / \mathrm{sec}$. 


\section{Redox behavior of caffeine in aqueous solution}

Cyclic voltammogram of $2.0 \times 10^{-3} \mathrm{M}$ caffeine in a mixture of $0.1 \mathrm{M} \mathrm{KCl}$ and small amount of dilute $\mathrm{NaOH}$ with a Pt-disc electrode is shown in Figure 2a. It exhibits a one step reversible process with a pair of anodic and cathodic peaks, which increase with increase in scan rate. The anodic peak is relatively broader and the cathodic peak is shifted towards more cathodic position with an increase of scan rate. The current potential data is compiled in Table 2. From the peak separation data and due to the presence of anodic and cathodic peaks (Figure 2a and Table 2), it can be suggested that caffeine shows redox behaviour with a quasi-reversible charge transfer. Shifting of cathodic potential towards more cathodic position suggests that the redox reaction (cathodic) becomes more difficult for caffeine with an increase of scan rate. Thus the less availability of the corresponding reducing product (desoxy caffeine anion intermediate) make anodic peak current broader than it is expected. The diffusion co-efficient, D was evaluated from the 'current- square root of scan rate' relationship from Figure $2 b$, and by using the following equation. ${ }^{14}$

$$
I_{p c}=2.69 \times 10^{5} \times n \times\left(\alpha n_{a}\right)^{1 / 2} A D^{1 / 2} C v^{1 / 2}
$$

Taking the geometric area of the Pt-disc electrode, $\mathrm{A}=0.025 \mathrm{~cm}^{2} ; \mathrm{C}=2.0 \times 10^{-3} \mathrm{M}\left(1 \times 10^{-6}\right.$ $\left.\mathrm{mol} / \mathrm{cm}^{3}\right), \mathrm{n}=1 ;\left(\alpha n_{a}\right)^{1 / 2}=$ obtained from the intercept from equation (3) for a quasireversible system; D for caffeine was calculated and the calculated value was recorded as $2.87 \times 10^{-6} \mathrm{~cm}^{2} / \mathrm{sec}$.

The heterogeneous charge transfer rate constant, $k_{f}$ for caffeine exhibiting a quasireversible charge transfer was calculated by using the theory described by Nicholson and Shain ${ }^{15}$ described in a review by Brown and Sandifer. ${ }^{14}$ Accordingly, we calculate the $k_{f}$ value by using the following equation.

$I_{p}=0.227 n F A C k_{f} \exp \left[\frac{\alpha n_{a} F}{R T}\left(E_{p}-E_{0}\right)\right]$

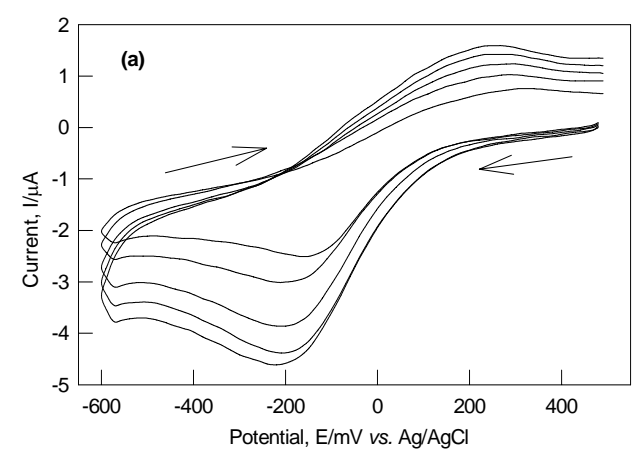

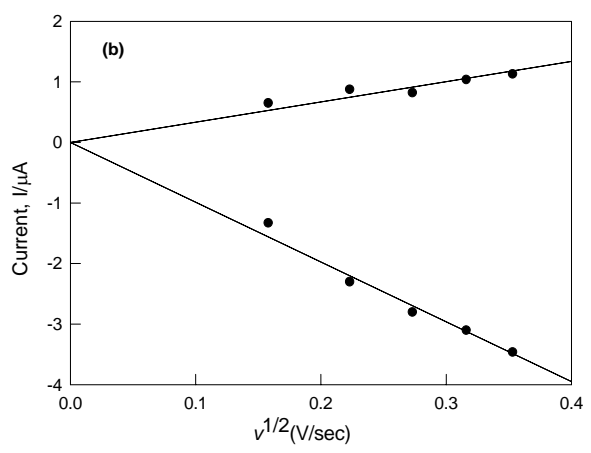

Fig. 2(a). $\mathrm{CV}$ of $1.2 \times 10^{-3} \mathrm{M}$ caffeine in a mixture of aqueous $\mathrm{KCl}$ and $\mathrm{NaOH}$ solution with a Pt-disc electrode at different scan rates and (b). Variation of anodic and cathodic peak currents with the square root of scan rates for the same solution 
Table 2. Current-potential data and calculated parameters from the CV of caffeine at different scan rates.

\begin{tabular}{cccccccc}
\hline$v / \mathrm{V} / \mathrm{sec}$ & $\sqrt{v}(\mathrm{~V} / \mathrm{sec})^{1 / 2}$ & $\mathrm{E}_{\mathrm{pa}} / \mathrm{mV}$ & $\begin{array}{c}-\mathrm{E}_{\mathrm{pc}} \\
/ \mathrm{mV}\end{array}$ & $\mathrm{I}_{\mathrm{pa}} / \mu \mathrm{A}$ & $\mathrm{I}_{\mathrm{pc}} / \mu \mathrm{A}$ & $\begin{array}{c}\Delta \mathrm{E}_{\mathrm{p}} / \\
\mathrm{mV}\end{array}$ & $\begin{array}{c}\mathrm{I}_{p a} / v^{1 / 2} \\
/(\mathrm{v} / \mathrm{sec})^{1 / 2}\end{array}$ \\
\hline 0.025 & 0.158 & 213 & 156 & 0.650 & 1.330 & 369 & 4.114 \\
0.050 & 0.223 & 250 & 200 & 0.877 & 2.300 & 450 & 3.933 \\
0.075 & 0.273 & 295 & 155 & 0.822 & 2.800 & 450 & 3.011 \\
0.100 & 0.316 & 218 & 204 & 1.037 & 3.100 & 422 & 3.282 \\
0.125 & 0.353 & 236 & 204 & 1.130 & 3.460 & 440 & 3.201 \\
\hline
\end{tabular}

$v=$ scan rate $; \mathrm{E}_{\mathrm{pa}}=$ anodic peak potential; $\mathrm{E}_{\mathrm{pc}}=$ cathodic peak potential; $\mathrm{I}_{\mathrm{pa}}=$ anodic peak current; $\mathrm{I}_{\mathrm{pc}}=$ cathodic peak current; $\Delta \mathrm{E}_{\mathrm{p}}=\left(\mathrm{E}_{\mathrm{pa}}-\mathrm{E}_{\mathrm{pc}}\right)=$ peak separation; $\mathrm{I}_{p a} / v^{1 / 2}=$ current function

A plot of $I_{p c} v s$. $C$ gave a straight line with a slope $0.227 n f A k_{f}$ (not shown in the figure). The value of $k_{f}$ was calculated from the slope. The calculated $k_{\mathrm{f}}$-value of caffeine was recorded as $1.10 \mathrm{~cm} / \mathrm{sec}$.

\section{Redox behavior of Fe in the presence of caffeine}

$\mathrm{Fe}$ in the presence of caffeine in the same electrolytic solution as above with a Pt-disc electrode shows a drastic change in the redox behavior of Fe. The redox potential was shifted to more cahthodic position compare to caffeine and $\mathrm{Fe}$ and peak current density was also reduced compare to $\mathrm{Fe}$ system. Cyclic voltammograms of $\mathrm{Fe}$ in the presence of caffeine at different scan rate is shown in Figure 3. This suggests that there is a strong interaction between Caffeine and Fe. The shifting of the potential towards negative value may be due to the adsorption of the oxidized species of caffeine. The diffusion coefficient $\mathrm{D}$, and heterogeneous charge transfer rate constant $k_{\mathrm{f}}$ was calculated by using equation (3) and (4) according to the previous section. The calculated value of the diffusion co-efficient, $\mathrm{D}$ and the heterogeneous charge transfer rate constant, $k_{\mathrm{f}}$ were recorded for caffeine in the presence of Fe $14.08 \times 10^{-6} \mathrm{~cm}^{2} / \mathrm{sec}$ and $15.01 \mathrm{~cm} / \mathrm{sec}$, respectively. The current-voltage data and the respective calculated parameters are tabulated in Table 3.

\section{Evidence of formation of complex between Caffeine and $\mathrm{Fe}$}

\section{Cyclic voltammetric evidence}

In order to find out whether any complex can be possible to form between caffeine and iron, we are trying to get qualitative information by using $\mathrm{CV}$ data. For this purpose, a comparative $\mathrm{CV}$ was constructed containing $\mathrm{Fe}\left(0.5 \times 10^{-3} \mathrm{M}\right)$, caffeine $\left(0.5 \times 10^{-3} \mathrm{M}\right)$ and Fe-caffeine system (each $0.5 \times 10^{-3} \mathrm{M}$ ) at a scan rate $50 \mathrm{mV} / \mathrm{sec}$. The $\mathrm{CV}$ is shown in Fig.4. According to Figure 4(a), it is observed that in case of Fe-caffeine complex, the
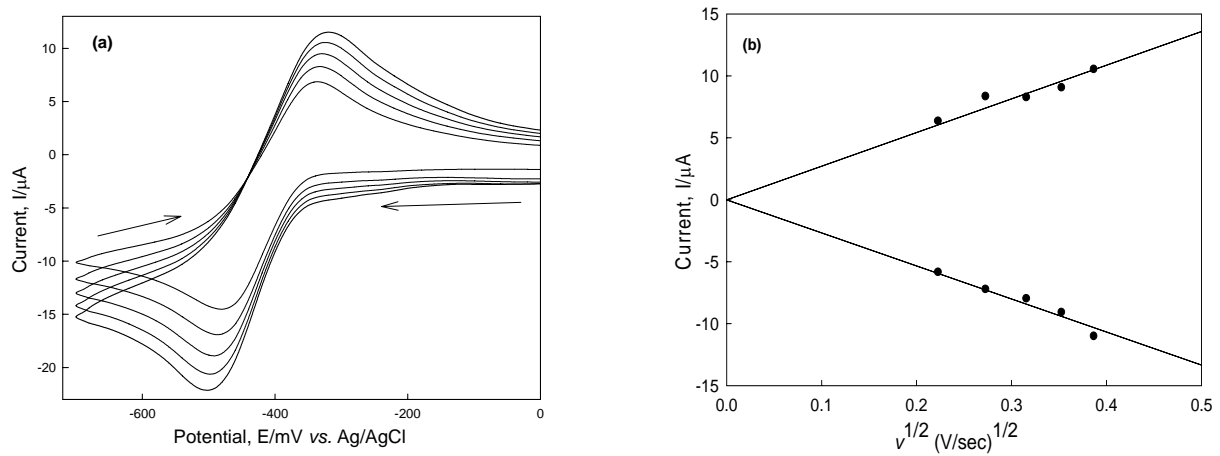
Fig. 3(a). $\mathrm{CV}$ of $1.2 \times 10^{-3} \mathrm{M} \mathrm{Fe}$ in the presence of $1.2 \times 10^{-3} \mathrm{M}$ caffeine in a mixture of aqueous $\mathrm{KCl}$ and dilute $\mathrm{NaOH}$ solution with a Pt-disc electrode at different scan rates and (b) Variation of anodic and cathodic peak currents with the square root of scan rates for the same solution.

Table 3. Current-potential data and calculated parameters from the CV of caffeine in the presence $\mathrm{Fe}$ at different scan rates

\begin{tabular}{llllllll}
\hline$v / \mathrm{V} / \mathrm{sec}$ & $\sqrt{v}(\mathrm{~V} / \mathrm{sec})^{1 / 2}$ & $-\mathrm{E}_{\mathrm{pa}} / \mathrm{mV}$ & $-\mathrm{E}_{\mathrm{pc}} / \mathrm{mV}$ & $\mathrm{I}_{\mathrm{pa}} / \mu \mathrm{A}$ & $\mathrm{I}_{\mathrm{pc}} / \mu \mathrm{A}$ & $\Delta \mathrm{E}_{\mathrm{p}} / \mathrm{mV}$ & $\begin{array}{c}\mathrm{I}_{p a} / v^{1 / 2} \\
/(\mathrm{v} / \mathrm{sec})^{1 / 2}\end{array}$ \\
\hline 0.025 & 0.158 & 331 & 475 & 6.32 & 5.87 & 144 & 26.32 \\
0.050 & 0.223 & 327 & 481 & 8.32 & 7.25 & 154 & 26.55 \\
0.075 & 0.273 & 328 & 484 & 8.25 & 8.01 & 156 & 25.35 \\
0.100 & 0.316 & 324 & 492 & 9.03 & 9.12 & 168 & 25.83 \\
0.125 & 0.353 & 315 & 501 & 10.51 & 11.04 & 186 & 28.52 \\
\hline
\end{tabular}

$v=$ scan rate $; \mathrm{E}_{\mathrm{pa}}=$ anodic peak potential; $\mathrm{E}_{\mathrm{pc}}=$ cathodic peak potential; $\mathrm{I}_{\mathrm{pa}}=$ anodic peak current;

$\mathrm{I}_{\mathrm{pc}}=$ cathodic peak current; $\Delta \mathrm{E}_{\mathrm{p}}=\left(\mathrm{E}_{\mathrm{pa}}-\mathrm{E}_{\mathrm{pc}}\right)=$ peak separation; $\mathrm{I}_{p a} / v^{1 / 2}=$ current function

anodic and cathodic peaks of $\mathrm{Fe}$ (Figure $4 \mathrm{~b}$ ) and caffeine (Figure $4 \mathrm{c}$ ) both were shifted to more cathodic position. The shifting of peak towards cathodic position also suggests that Fe-caffeine complex is very much stable and oxidation and/or reduction are rather difficult in the complex as compare to pure iron and caffeine in aqueous media. But the diffusion and the charge transfer process for Fe-caffeine complex are more rapid as compare to caffeine and less rapid as compare to pure Fe. This suggests that the absorption of $\mathrm{Fe}$ with caffeine will decrease the diffusion ability of any species (viz oxygen) in a mixture of caffeine and Fe in aqueous media.

Furthermore, diffusion co-efficient and heterogeneous charge transfer rate constants were calculated for Fe, Caffeine and Fe-Caffeine system and tabulated in Table 4. The differences of the value of $\mathrm{D}$ and $k_{\mathrm{f}}$ from that of the values of $\mathrm{Fe}$ and caffeine systems easily recognize that there must be a complex formed between $\mathrm{Fe}$ and Caffeine. 

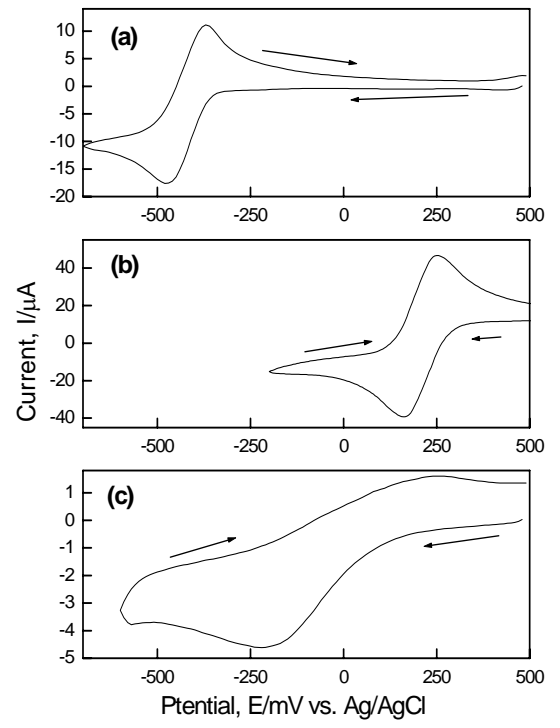

Fig. 4. Comparative CVs of (a). Fe $\left(0.5 \times 10^{-3} \mathrm{M}\right)$, (b). caffeine $\left(0.5 \times 10^{-3} \mathrm{M}\right)$ and (c). Fe-caffeine complex (each $0.5 \times 10^{-3} \mathrm{M}$ ) in $0.1 \mathrm{M} \mathrm{KCl}$ solution containing a small amount of $\mathrm{NaOH}$ solution $(\mathrm{pH} 7.4)$. Scan rate for all of the cases $50 \mathrm{mV} / \mathrm{sec}$.

Table 4. Comparative diffusion and kinetic parameters of $0.6 \times 10^{-3} \mathrm{M} \mathrm{Fe}, 0.6 \times 10^{-3}$ $\mathrm{M}$ caffeine, and Fe- caffeine complex in a mixture of $0.01 \mathrm{M} \mathrm{KCl}$ and dilute $\mathrm{NaOH}$ solution (pH 7.4) at scan rate $50 \mathrm{mV} / \mathrm{sec}$.

\begin{tabular}{cccc}
\hline System & Concentration $/ \mathrm{mM}$ & $\begin{array}{c}\text { Diffusion } \\
\text { coefficient } / \\
\mathrm{D} \times 10^{6} \mathrm{~cm}^{2} / \mathrm{sec}\end{array}$ & $\begin{array}{c}\text { Heterogeneous charge transfer } \\
\text { rate constant, } k_{\mathrm{f}} \times 10^{3} \mathrm{~cm} / \mathrm{s}\end{array}$ \\
\hline $\mathrm{Fe}$ & 0.5 & 17.30 & 16.1 \\
Caffeine & 0.5 & 1.30 & 1.10 \\
$\mathrm{Fe}+$ caffeine $]$ & $1: 1$ ratio & 3.60 & 4.70 \\
\hline
\end{tabular}

Chronocoulometric (CC) study of the interaction between Fe and caffeine

Double potential step CC was employed to elucidate the initial stage of diffusion coefficient $\left(\mathrm{D}^{\circ}\right)$ and heterogeneous charge transfer rate constant $\left(k_{\mathrm{f}}^{\mathrm{o}}\right)$ at the initial stage of diffusion of $\mathrm{Fe}$, caffeine and Fe-caffeine complex. Complexation between $\mathrm{Fe}$ and caffeine can be further confirmed from the comparative background subtracted $\mathrm{CC}$ of 
Fe,caffeine and Fe-caffeine system, which was shown in Figure 5. The values of the initial stage of diffusion co-efficient $\left(\mathrm{D}^{\circ}\right)$ and heterogeneous charge transfer rate constant $\left(k_{\mathrm{f}}^{\mathrm{o}}\right)$ at the initial stage of diffusion for different species are calculated by using published papers. ${ }^{16-17}$

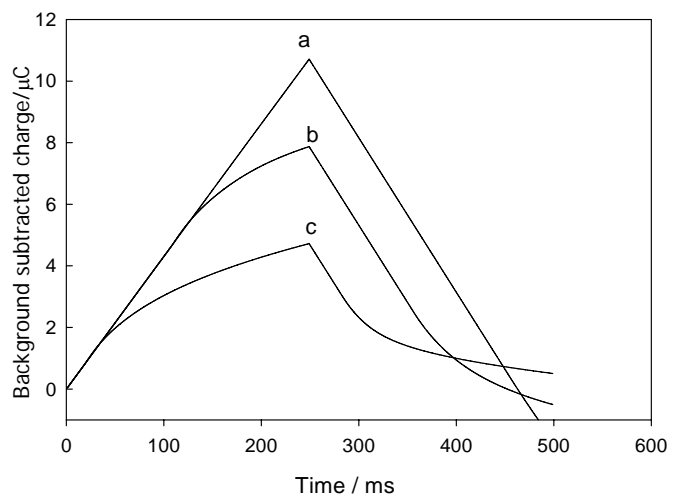

Fig. 5. Relative chronocoulograms of (a) $1 \mathrm{mM} \mathrm{Fe}$, (b) Fe-caffeine complex (molar ratio=1:1) and (c) $1 \mathrm{mM}$ caffeine solution in a mixture of $0.1 \mathrm{mM} \mathrm{KCl}$ and dilute $\mathrm{NaOH}$ solution at a Pt-disc electrode.

Table 5 represents comparative data of different electrodics parameters for Fe, caffeine and Fe-caffeine complex obtained from double potential step CC data.

Table 5. Comparative calculated parameters for Fe and Fe-caffeine complex from CC data

\begin{tabular}{lllll}
\hline System & $\begin{array}{l}\text { Diffusion } \\
\text { coefficients } \\
\left(\mathrm{D}^{\circ}\right) \times 10^{6} \mathrm{~cm}^{2} / \mathrm{sec}\end{array}$ & $\begin{array}{l}\text { Tafel slope } \\
\times 10^{6}\end{array}$ & $\begin{array}{l}\mathrm{t}_{\mathrm{i}}^{1 / 2} \text { or } \theta^{1 / 2} \\
\text { (time to cross } \\
\text { double layer) } / \mathrm{msec}\end{array}$ & $\begin{array}{l}\text { Hetergeneous } \\
\text { electron transfer rate } \\
\text { constant }\left(k_{\mathrm{f}}^{\mathrm{f}}\right) \times 10^{3} \\
\mathrm{~cm} / \mathrm{sec}\end{array}$ \\
\hline Caffeine & 12.02 & 15.21 & 0.21 & 13.53 \\
Fe(II) & 25.2 & 27.341 & 0.22 & 18.23 \\
Fe-caffeine & 40.0 & 110.07 & 0.24 & 37.40 \\
\hline
\end{tabular}




\section{Differential pulse voltammetric (DPV) evidence}

The formation of the complex between Fe and Caffeine was further examined by DPV. Figure 6 represents the comparative DPVs of Fe (peak a) Caffeine (peak b) and $\mathrm{Fe}-\mathrm{Caffeine}$ complex (peak c). From the figure, we can see that the peak of Fe and caffeine was shifted cathodically for Fe-caffeine complex. This shifting of the peak of $\mathrm{Fe}$ and caffeine indicate that the cathodic shifted peak around at $-350 \mathrm{mV}$ is due to $\mathrm{Fe}$ caffeine complex. This data also supports the $\mathrm{CV}$ data explained in the previous section. The current density of Fe in the presence of caffeine also decreases drastically due to the utilization of current (directly proportional to the concentration) for the complex formation between $\mathrm{Fe}$ and caffeine.

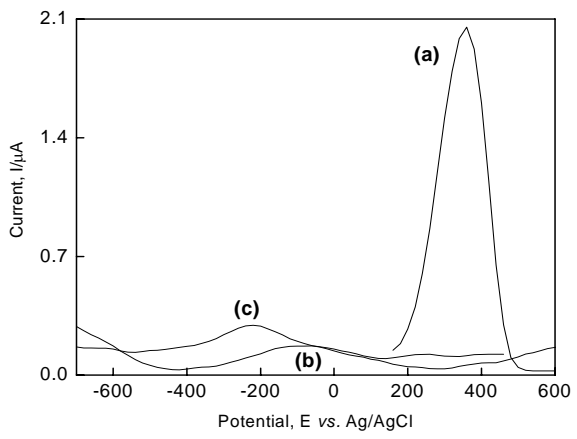

Fig. 6. Comparative DPVs of $0.5 \times 10^{-3} \mathrm{M}$ (a) Fe, (b) caffeine and (c) Fe-caffeine complex (1:1 ratio).

Determination of the speciation of Fe-caffeine complex was targeted by using DPV data. For this purpose, in $0.3 \mathrm{mM}$ Fe solution, a gradual addition of caffeine solution was carried out and the peak current density from the DPV was recorded and plotted against the concentration of caffeine solution. It was observed that initially current density was decreased but after the concentration of caffeine solution is reached at $0.3 \mathrm{mM}$, the peak current density was increased again. From the point of inflection according to Figure 7, we can conclude that a 1:1 complex is formed between Fe and caffeine.

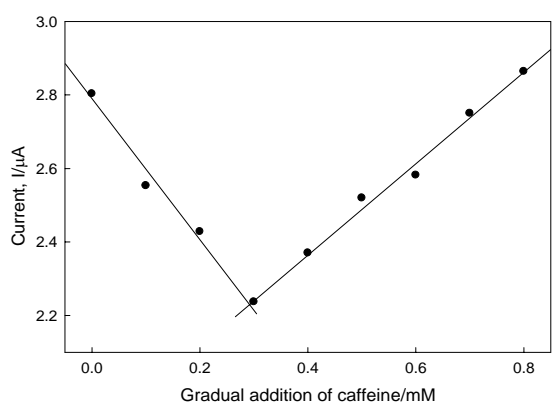

Fig. 7. Changing of peak current obtained from a series of DPVs of $0.3 \times 10^{-3} \mathrm{M} \mathrm{Fe}$ after gradual addition of $0.3 \times 10^{-3} \mathrm{M}$ caffeine in aqueous solution. 


\section{$U V$-visible spectroscopic evidence}

The formation of the complex between Fe and caffeine was further examined by UVvisible spectroscopy. The UV-visible spectra of $1 \mathrm{mM} \mathrm{Fe}$, caffeine and Fe-caffeine complex is shown in Figure 8(a), 8(b) and 8(c). From the comparative spectrum, it was clearly observed that the absorption peak near $240 \mathrm{~nm}$ for caffeine was distorted from the addition of $\mathrm{Fe}$ solution. A broad peak was observed (Figure 8c) for the Fe-caffeine complex instead of sharp peak. This change is obviously due to the formation of the complex between Fe and caffeine. Further the absorbance of caffeine was reduced due to absorption of caffeine by Fe for the Fe-caffeine complex formation.
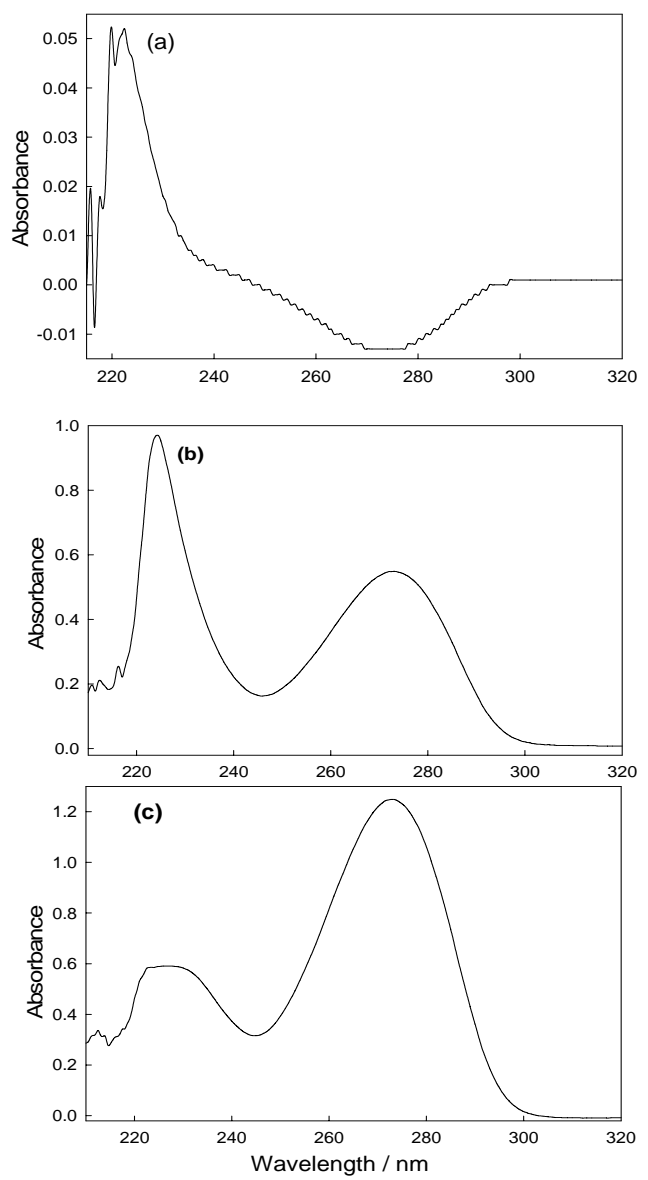

Fig. 8. Comparative UV-visible spectrum of (a). Caffeine( $1 \mathrm{mM})$, (b). $\mathrm{Fe}^{2+}(1 \mathrm{mM})$ and (c). Fecaffeine complex (molar ratio 1:1). 
Job's method for the elucidation of the empirical formula of complex was employed for the further confirmation to form the complex between Fe and caffeine. Figure 9 represents the Job's plot to elucidate the empirical formula of the Fe-caffeine complex from which it can be concluded that the complexation between Fe and caffeine was occurred with a 1:1 molar ratio.

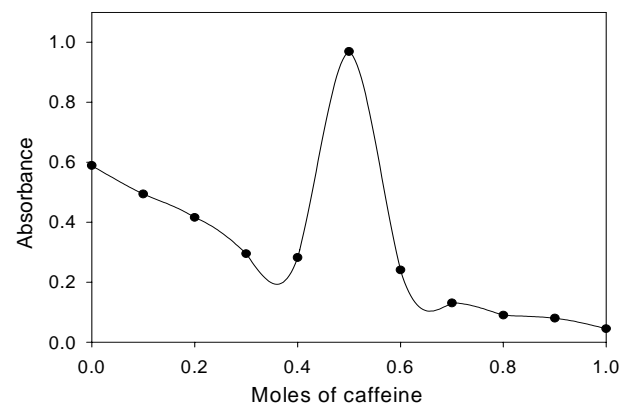

Fig. 9. Job's plot for the speciation of Fe-caffeine complex.

\section{Theoretical calculation for detection of active site for Caffeine}

Theoretical calculation was done by using MOPAC semi-empirical computational calaculation (PM3) to find the reactive center of caffeine to bind with Fe. ${ }^{18}$ The relative charge density for different elements in caffeine is listed in Table 6. From the calculation it is obtained that the electron cloud is positioned at the highest spin density region between $\mathrm{O}(33)$ and $\mathrm{O}(34)$ positions. The design of the Fe-caffeine complex is to fit into the active site of the caffeine. A good ligand needs a suitable geometry and also appropriate electrostatic properties. From Figure 10, we can see that the caffeine surface is almost spherical. Therefore, the electrostatic properties of the caffeine should complement those to the Fe ions. Here we present a method for the assignment of atomcentered point charges for caffeine, based on the electrostatic potential and charge. Thus a 1:1 Fe-caffeine complex was formed between $\mathrm{O}(33)$ and $\mathrm{O}(34)$ positions of caffeine. Figure 10 showed the electrostatic potential map, which provides an indicator for the charge distribution in the caffeine molecule.
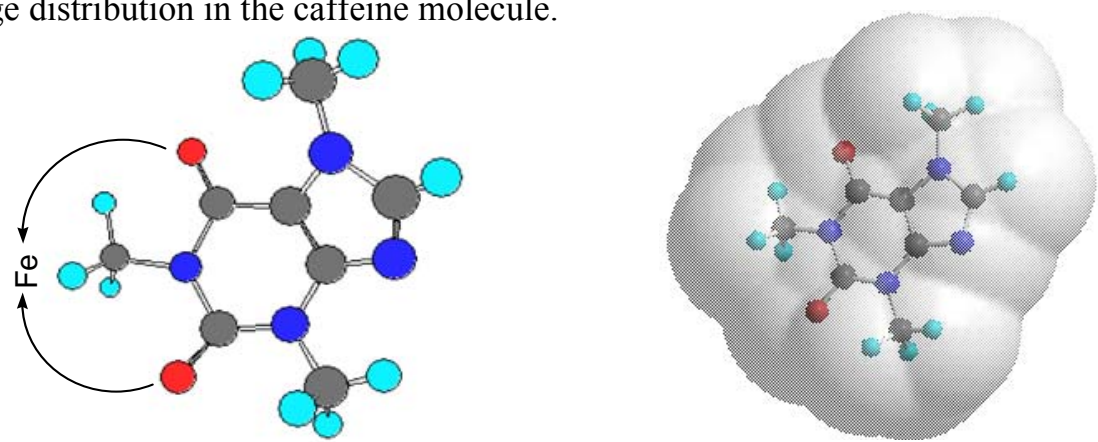

Fig. 10. Structure of Fe-caffeine complex attaching at the active centers and electrostatic potential surface of caffeine after energy minimization. 
Table 6. MOPAC data for the charge density and electrostatic potential charge of different atoms

\begin{tabular}{ccc}
\hline Atom number & Charge & $\begin{array}{c}\text { Electrostatic Potential Charges } \\
\text { (Dielectric Constant }=78.50)\end{array}$ \\
\hline $\mathrm{C}(20)$ & 0.12632 & 0.30946 \\
$\mathrm{C}(21)$ & 0.22213 & 0.48723 \\
$\mathrm{C}(22)$ & 0.47182 & 0.52087 \\
$\mathrm{~N}(23)$ & -0.42950 & -0.20719 \\
$\mathrm{C}(24)$ & 0.50635 & 0.46665 \\
$\mathrm{~N}(25)$ & -0.35095 & -0.17978 \\
$\mathrm{~N}(26)$ & -0.18774 & -0.43548 \\
$\mathrm{C}(27)$ & 0.05753 & 0.06736 \\
$\mathrm{~N}(28)$ & -0.23201 & 0.15685 \\
$\mathrm{C}(29)$ & 0.19556 & 0.38252 \\
$\mathbf{O}(33)$ & $\mathbf{- 0 . 3 7 2 6 9}$ & $\mathbf{- 0 . 4 4 6 7 7}$ \\
$\mathbf{O}(\mathbf{3 4})$ & $\mathbf{- 0 . 3 8 8 1 2}$ & $\mathbf{- 0 . 4 5 6 8 0}$ \\
$\mathrm{C}(35)$ & 0.18345 & 0.38791 \\
$\mathrm{C}(39)$ & 0.19506 & 0.48990 \\
\hline
\end{tabular}

Heat of Formation of caffeine calculated: $8.942 \mathrm{kcal} / \mathrm{mol}$; arbitrary dihedral chosen for $\mathrm{C}(2)-\mathrm{N}(17)-\mathrm{C}(18)-\mathrm{H}(19)$

\section{Conclusion}

The higher absorption of $\mathrm{Fe}$ in the presence of caffeine is caused due to the formation of the complex between caffeine and Fe. Different types of physiological problems may be occurred due to the influence of caffeine results from slow heterogeneous charge transfer of $\mathrm{Fe}$ at a physiological $\mathrm{pH}$ in the electrolytic media. It is revealed from the present research that Fe-caffeine complex was formed with 1:1 ratio between the $\mathrm{O}(33)$ and $\mathrm{O}(34)$ positions of caffeine.

\section{References}

1. M. U. Eteng, E. U. E. O. Eyong, M. A. Akpanyong, and C. Y. Aremu, Plant Food for Human Nutrit., 1997, 51, 231.

2. M. S. Shils, J. A. Olson, M. Shike, "Iron in Medicine and Nutrition. Modern Nutrition and Health and Disease", ( $8^{\text {th }}$ edition), Lea and Fbiger, Philadelphia, 1994, p 185.

3. R. Garrison and E. Somer, "Nutrition Desk Reference", Keats Publishing, Inc. Connecticut, 1995, USA.

4. M. Margaret, J. Nutr. \& Environ. Med., 2007, 16(2), 149. 
5. B. K. Martijn and E. Schouten, Am. J. Clin. Nutr., 2005, 81, 539.

6. C. Cao, D. A. Loewenstein, X. Lin, C. Zhang, L. Wang, R. Duara, Y. Wu, A. Giannini, G. Bai, J. Cai, M. Greig, E. Schofield, R. Ashok, B. Small, H. Potter, G. W. Arendash, J. Alzheimer's Disease, 2012, 3, 559.

7. A. E. Abara, G. O. Obochi, S. P. Malu, M. Obi-abang, V. S. Ekam, F. U. Uboh, Nigerian Journal of Physiological Sciences, 2007, 22(1-2), 75.

8. D. S. Kim and R. D. Palmiter, Proc. Natl. Acad. Sci., 2003, Neuroscience, 100(3), 1346.

9. J. M. Davis, Z. Zhao, H. S. Stock, K. A. Mehl, J. Buggy, G. A. Hand, Am. J. Physiol., Regu. Physiol., 2003, 284(2), 399.

10. S. Jana, IASP (Pain), 2011, 152, 726.

11. P. N. Vyleta and S. M. Smith, PLoS ONE, 2008, 3(9), 3155.

12. M. Yaheya and M. Ismail, Asian Journal of Pharmaceutical and Clinical Research, 2009 , 2(4), 1.

13. N. Spataru, B. Sarada, D. A. Tryk, and A. Fujishima, Electroanalysis, 2002, 14(11), 721.

14. B. W. Rossiter and J. F. Hamilton, "Physical Method of Chemistry, Electrochemical Methods", Vol II, John Wiley and Sons. Inc. New York, 1986.

15. R. S. Nicholson and I. Shain, 1964, Anal. Chem., 36, 706.

16. F. C. Anson and R. A Osteryoung, J. Chem. Educ. 1983, 60, 293.

17. M. A. Jabbar, H. Shimakoshi and Y. Hisaeda, Chem Commun, 2007, 1653.

18. T. Clark, "A Handbook of Computational Chemistry”, Wiley, New York, 1985. 